\title{
ТОМОГРАФИЯ В ТРАНЗИТНОЙ ЗОНЕ: ВОЗМОЖНОСТИ И ПЕРСПЕКТИВЫ
}

Рослов Ю.В., Дергунов Н.Т., Ефимова Н.Н. (ФГУ НПП «Севморгео»)

Основные технологические особенности при работах на мелководье (наличие повышенного природного сейсмического шума, необходимость увязки с наземными профилями, зоны вечной мерзлоты) обуславливают необходимость дополнения стандартных методик обработки сейсмической информации сейсмотомографической инверсией. Методнка проведения сейсмических работ МОВ-ОГТ в транзитной зоне с использованием телеметрической системы "ВОХ" обеспеqивает получение сейсмических записей с большими удалениями истодник приемник (10-12 км). Такая методика работ позволяет достаточно уверенно прослеживать как отраженные, так и преломленные волны и открывает перспективы использования сейсмотомографической обработки годографов первьгх и последуюших волн при интерпретации сейсмических данных.

В представленньгх тезисах рассмотрен подход, позволяющий получить скоростную модель на вско глубину разреза по кинематическим характеристикам отраженных волн на основе модифицированного томографического алгоритма инверсии преломленных и отраженных волн Дитмара-Рослова, реализованного в системе томографической обработки ХТОМО. Совместная обработка преломленных и отраженных волн позволяет увеличить глубинность исследований и повысить достоверность скоростных восстановлений за счет использования большего количества входной информации и лучшего азимутального покрытия лучами элементов среды.

Основная идея применения томографического подхода состояла в разделении структурновешественных комплексов среды по скоростным параметрам. Поскольку скорость продольньх волн в нефтегазонасыщенных породах значительно ниже, чем в водонасыщенных породах, то, возможно, использовать зоны аномально низких значений скорости на сейсмотомографическом разрезе для прогноза газовых и нефтяных залежей.

Для изучения возможности прогноза газовых залежей по результатам сейсмотомо-графической обработки использовались сейсмические данные на профиле, расположенном в пределах ОбскоТазовскогого мелководья. В интервале разреза нижнего мела - верхней юоры (между горизонтами $\mathrm{M}$ и Б) выделены по ряду признаков контуры залежей УВ, которые находят отражение на разрезе мгновенньх амплитуд в виде аномальньх значений амплитуд в пределах известного месторождения УВ (рис.1,a). На сейсмотомографическом скоростном разрезе в пределах этого интервала разреза выделяются 4 зоны аномально пониженных значений скорости (рис1,6).
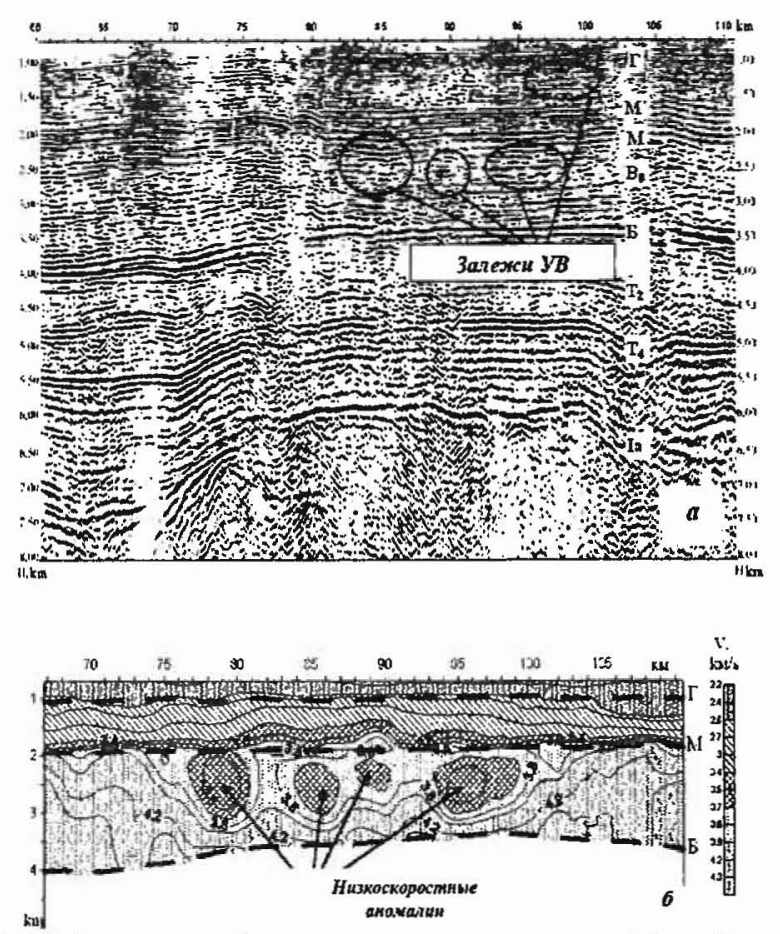

Рис.1 Фрагмент гтубинного динамического разреза (а) и сейсмотомографический скоростной разрез (б) в пределах известного нефтегазового месторождения.

Предлагаемая технология направлена на повышение эффективности геологоразведочных работ, и снижение геологических рисков. На примере сейсмических материалов, полученных в транзитной зоне Обской губы, показана перспективность использования сейсмотомографического скоростного разреза в качестве дополнительного критерия для прогноза залежей углеводородов. Особенно актуально использование этого дополнительного параметра в случаях, когда залежь не проявляется в виде "яркого пятна". Если скорость в породе-коллекторе ниже, чем в перекрывағощих отложениях, залежь может проявляться в виде "бледного пятна". Выделение таких залежей - более трудная задача, решению которой может помочь сейсмотомографическая обработка. 